CENTRE FOR ECONOMIC PERFORMANCE

OCCASIONAL PAPER NO. 6

AUGUST 1994

INCURABLE UNEMPLOYMENT:

A PROGRESSIVE DISEASE OF MODERN SOCIETIES?

R. DORE 


\begin{abstract}
It is widely acknowledged that the contemporary unemployment problem is very largely a problem of unemployed unskilled workers. This paper argues (a) that high levels of unemployment and increasing dispersion in the primary labour income distribution are intimately related; (b) that both reflect the impact of the accumulation of technology on the job structure; (c) skill shortages are to be explained in increasing part by limits to the available stock of learning ability as well as to inefficiencies in training institutions; (d) a sizeable quantum of existing unemployment arises because the market clearing wage for people of low learning ability falls below either a statutory minimum wage or the reservation wage as set by the social security minimum; (e) adequate discussion of these hypotheses is inhibited by a variety of taboos.

Going from analysis to prescription, the paper argues that the more serious social problem is not unemployment per se, but the increasing inequality of condition of which it is a symptom. It seems particularly important to stress this, given that about the only cure for unemployment on offer seems to be greater "flexibility" -- reduction of worker-protection "rigidities" -- which would increase inequality; making the cure worse than the disease.

Seemingly utopian long-run cures are considered, primarily moving towards a reasonably adequate universal citizen's income. This so redefines the rights and duties of citizenship that the necessary redistribution is seen not as taking from the able and industrious to give to the feckless, but as taking from the gifted lucky ones who can get satisfying work, in order to give both to the unlucky ones who cannot work and to those who could work -- but who choose to do other things.
\end{abstract}

This paper was produced as part of the Centre's

Programme on Business Policy 


\section{INCURABLE UNEMPLOYMENT: \\ A PROGRESSIVE DISEASE OF MODERN SOCIETIES?}

Ronald Dore

Page

1. Background 1

2. Modern Unemployment 9

3. Prescriptions: Better VET 15

4. Alternative Prescriptions:

Active Labour Market Policies, etc $\quad 18$

5. Long-term Problems: Long-term

Solutions

6. Objections 23

$\begin{array}{ll}\text { Endnotes } & 28\end{array}$

The Centre for Economic Performance is financed by the Economic and Social Research Council. 


\title{
INCURABLE UNEMPLOYMENT: A PROGRESSIVE DISEASE OF MODERN SOCIETIES?
}

\author{
Ronald Dore
}

\section{Background}

The interpretation of our current unemployment problems which follows has never seemed to persuade any audience on whom I have tried it out over the last 8 years. The only variation is in the mix of incredulity, embarrassment and outrage with which it is greeted. This has led me to wonder what peculiarity or defect of character it might be that causes me to continue to find it the most plausible interpretation available. I have concluded that there might be several factors all stemming (a) from my advanced age, and (b) from the fact that I have spent most of my life studying the Japanese economy and society. It might be as well to begin by spelling out those factors -- to explain, as Americans say, where I'm coming from.

1.1. I am old enough to have heard Tawney give a public lecture, somewhere around 1949, in which he celebrated the redistribution of wealth which the Labour government's new taxation system would ensure. It would, he said, have revolutionary implications in ending the inequalities he had so eloquently written about. Soon after that I went to Japan and saw the effects of an even more drastic wealth redistribution.

But gross inequalities of condition are still there and are still a central political issue in Britain, if less so in Japan. But as compared with the time when Tawney's Equality ${ }^{1}$ was published, asset ownership is, indeed, a less obvious cause of inequality. If one were to look for "two nations" in the Disraeli sense today, where would one look for the dividing line? When he spoke of the Rich and the Poor as being totally out of touch with each other -- "no intercourse and no sympathy", "as ignorant of each other's habits, thought and feeling as if they were dwellers in different zones or inhabitants of different planets" ${ }^{2}$, he had in mind the gulf between the aristocracy, gentry and professional and commercial upper middle class -- some two per cent of the population, perhaps -- and the other 98 per cent. When the Clarendon Committee on the grammar schools started, a couple of decades later, to estimate the size of the "middle class" that needed grammar schools, they came up with a figure around five per cent. Today's equivalent, in that dimension of "sympathy, habits, thought and feeling", would presumably be the 20 per cent of the population who read the quality papers and the rest who read what a journalist recently called the tabloids and testosteroids or nothing.

But that "taste and sentiment" dividing line would not today also, as it was in Disraeli's time, be the most obviously significant dividing line in 
terms of asset ownership. That line, surely, is the one which lies between the 60 per cent who own their own home and a car, possibly a private pension of some sort, and the 40 per cent who do not.

And -- the essential point -- both of today's dividing lines would correspond, roughly, with the distribution of earned income.

What Tawney was celebrating in 1949, in other words, was the arrival of meritocracy, the shift from a traditional society in which asset inequality and inequality of unearned income from capital was the dominant determinant of inequality of condition, to a society in which inequalities of earned income are the dominant factor -- not only from an increase in the labour share in GNP, but also from an increasing capture of capital income by pension funds and insurance companies -- and ultimately by the large numbers of people who have pensions and policies.

The shift parallels the common observation that in the production process human capital has become steadily more important relative to material capital. Likewise, in generating income inequality, differences in individual endowments of human capital are more important than differences in endowments of wealth.

1.2. The second point concerns something which colours my thinking about the factors which generate those increasingly important differences in earning power. I am old enough to have begun reading sociology during the fifties when there was still a journal called the Eugenics Review, when the relative role of nature and nurture in generating human differences was still a lively topic of debate, when people still took the concept of intelligence seriously. That was the decade which saw the publication of two of the most perceptive anti-utopias in which genetic endowments play a crucial role -- Kurt Vonnegut's Player Piano, and Michael Young's Rise of the Meritocracy, with its famous equation "Merit = IQ+Effort"

So I was also around to see the steady imposition of a taboo on such discussions in the 1960s; the banishment of such concepts as "intelligence" from the discussion of skills and ability, the marginalization into what were generally labelled as right-wing ghettoes of psychologists such as Hans Eysenck who persisted in discussing the heredity element in ability differences, (all you need to do at the mention of such a topic is say "Yah! Cyril Burt!") and the dwindling to a mere trickle of the only kind of research which provides really substantial scientific evidence on the nature/nurture question, namely the systematic comparisons of siblings and identical twins reared together and reared apart.

While I understand and sympathize with the generous concern for the self-respect and dignity of the not-so-bright which lies behind this taboo, and while being, personally, still strongly in favour of comprehensive 
rather than selective education at least until the mid-teens, the acceptance of this taboo by academics has always seemed to me a sort of trahison des clercs. It seriously impedes the careful, and socially responsible, analysis of important social problems.

An example of what I would call social irresponsibility, or less brutally an evasion of social responsibility, is the second pamphlet of the Commission on Social Justice, The Justice Gap. It not only maps the pattern of inequality, it also discusses the way inequality is inherited from generation to generation. It suggests that equality of opportunity can be made into a very radical ideal if it means changing society so that the most disadvantaged get the same life-chances as the more fortunate. It goes on to say that the changes this would require can be very wide-ranging indeed, and that education is the "crucial means".

But how wide-ranging, and through what form of education, depends crucially on what are the actual mechanisms of intergeneration transmission. How much of the variance in inherited opportunity is to be attributed to the two factors that social intervention can operate to alter: the economic factors -- some parents having more to spend on their children than others -- or the cultural factors -- different parents using their resources differently, giving exposure in the family to different qualities of spoken language, expressions of different emotions, values and aspirations, the content of different newspapers or TV programmes. And how much of the variance is, instead, to be attributed to genetic factors -- the fact that, for all the regression towards the mean, brighter and more energetic parents tend to have brighter and more energetic children.

There are answers to that question. The most authoritative one known to $\mathrm{me}^{3}$-- the result of a careful study of 2478 pairs of American male twins on the National Academy of Sciences-National Research Council twin registry -- concludes that, given the variations of environments and of gene packages found in American post-war society, "inequality of opportunity [defined so as not to "incorporate inequalities of genotype"] accounts for less than 20 per cent of the variance in outcomes. [Occupational status, earnings, etc.] Thus, equalizing opportunities in this [environmental] sense would to a limited degree equalize outcomes without necessarily requiring any inefficient disincentives. However, total family effects, including genetics, account for about 60 per cent of the variance of outcomes."

The bulk of the people in that sample were born in the first half of this century. The odds are that for later generations the role of genetic factors will be greater than that 40 per cent. There has been a significant increase in equality of educational opportunity, (how many people as bright as Ernie Bevin would now leave school at 16, let alone 13?). And any 
homogenization of environments reduces the role of nurture in explaining differences in outcomes, and enhances that of nature.

In any case, it seems to me axiomatic that unless one takes seriously that question about the relative importance of genetic as opposed to social and cultural mechanisms -- and the available answers to it -- the designing of educational systems or employment systems or welfare systems to break the cycle of generational transmission -- to reverse the progressive disconnection of the "underclass" from society (to use terminology which again is taboo for members of the Commission on Social Justice) -becomes impossible. The Justice Gap, observing the taboos, managed to avoid the question completely.

1.3. My third peculiarity, relevant precisely to the notion of "disconnection from society" is a long history of trying to worry out the implications of the contrast between British "individualism" and the Japanese sense of community -- recently restimulated by getting to know more about both American individualism and the Italian sense of community. I have become convinced that a key concept in all the discussion of the future of welfare and social security systems -- not only for understanding, but also for policy formulation -- is that of sharing.

If we are going to have a half-way decent society to live in, we are going to have to have a good deal more sharing between the lucky and the unlucky. And the willingness to accept that sharing -- both the willingness to give and the willingness to receive without feeling resentment -- depend crucially on the sense of community, -- on fraternity, the third of the French Revolution's trinity of virtues, too often forgotten in the British preoccupation with the other two.

It seems to me a pity that a rethink of the welfare state should take place under the rubric of a Commission on Social Justice. I can understand, if not applaud, the Commission's valiant effort to stem the tide of relativist ethics and reassert the Platonic realist view that there is such a "thing" as social justice whose nature and implications it was the job of the Commission to discover and lay bare. But its first pamphlet which tried to do this, succeeded only in showing the unreconcilable diversity of individual ideas of fairness. They do not begin to have a method for reconciling by logic -- rather than by the persuasion of emotional appeal -the difference between, say, Mr. A who says:

"the quarter million a year I can earn as a CEO, represents an impersonal market valuation of my contribution to society, and as such is a fair reward for my work. The fact that people who 
make lesser contribution are sleeping in the streets is no reason why I shouldn't keep every penny of it",

and a Rawlsian Mr. B who says:

"it's implausible that Mr. A would have chosen that distributional arrangement behind a veil of ignorance as to what sort of slot he would occupy in society. Therefore, in all fairness, he should not argue as he does",

or Mr. C who says something similar in more simple words:

"my idea of fairness concentrates on effort. People should not be rewarded simply for their luck in being bright and able to make a social contribution that the market values more highly than others. Equal efforts to use such talents as one has should get equal rewards.

That philosophical disagreement will stretch to the end of time. But around which of these versions the predominant consensus in any society will in practice converge is a question determined by social factors, among which the sense of community and the willingness to share (preferably from sentiments of fraternalism rather than the charitable paternalism which Mrs. Thatcher advocated) are overwhelmingly important.

The willingness to share and an acute sense of fairness are not the same thing. It is a safe bet that, if asked to share the rewards the market gives them, Messrs. A, B and $\mathrm{C}$ would all prove to be more willing to share with a close family member than with a distant cousin, and more willing to share with a distant cousin than with any old Tom, Dick or Harriet. Measurements of "social distance" played a prominent part in the first sociology textbooks I read in the 1950s, and they remain crucial for the discussion of welfare and the possibilities of redistribution. The extent of fellow-feeling within a social group, the sense among fellow-citizens that they belong to a national community, is what determines the willingness to share, to accept taxation to increase the social wage or transfer purchasing power. What concept of fairness, of justice, predominates is a function of the degree to which that sense of community is actually present, it is not the fundamental starting point.

Justice becomes the only starting point left, if one accepts that the sense of community has been fatally eroded to vanishing point, and we have become a society of atomised individualistic individuals. I fear that the fact that it has become the fundamental starting point for the work of 
the Commission on Social Justice, does indeed reflect such an assumption. There is a contrast between the very vocal concern of the Italian and German left with the possibilities of transforming class solidarity into social solidarity ${ }^{4}$, and the continued preoccupation of the Labour Party with individual rights and entitlements -- the fact that the defenders of the National Health Service, for instance, don't have much to say about its symbolic importance as social bond -- as "our" health service. In this, it seems to me, the Italians are closer to getting it right and the Labour Party to getting it wrong.

Perhaps the Labour Party had no other place to go, given that the Christian Socialist strain in Labour Party collectivism which had its heyday in the late 1940s always was a minor theme. The authors of the SCPR reports on British social attitudes remark that their surveys confirm that "class interest, and not moral values (such as attitudes to welfare dependency) is the most important factor dividing the parties in British politics. Of the 18 statements which most sharply divided Labour from Conservative supporters in 1985 and 1986, 14 were to do with class interest -- the other 4 were to do with nuclear weapons on British soil and socialist planning versus private enterprise" ${ }^{15}$.

But I do not believe that we have to give up. I do not think we should abandon society -- community -- to the individual. The British left has enjoyed pouring scorn on Mrs Thatcher's famous "there is no such thing as society", but what is it doing to prevent her assertion becoming a true prediction? We need to think seriously about the means -- the "social engineering means" if you like -- of reconstituting it.

1.4. The final peculiarity which has shaped my perceptions of the employment problem is a deep interest in one of the crucial mechanisms of meritocracy -- the role of educational selection ("credentialism") in modern industrial societies. No student of Japanese society could fail to be interested in such matters. In my case that interest, stimulated in Japan, was carried over into subsequent research in Sri Lanka and other developing countries and resulted in a book entitled The Diploma Disease. The thesis of that book is briefly:

More and more of the worthwhile "jobs" in modern societies are part of a patterned "career".

People are selected for careers relatively early in life -- by employing organizations, or by the institutions which offer the vocational courses leading to career-licensing qualifications -- increasingly on the basis of their educational qualifications. 
Those educational qualifications are increasingly used less as measures of what people have already learned than as surrogate measures of an individual's position in the spectrum of learning abilities -- more or less correlating, in most definitions of the term, with "intelligence". That is why a first in classics is as good a qualification as a first in economics for a job -- or rather a career -- in the Treasury. And that is why, in selection for nurses' training courses or engineering technician courses in Britain, a GCSE credit in vocationally relevant subjects like domestic science or mechanical drawing cuts very little ice. Selectors look rather at scores on the more "intellectually rigorous" English and Maths exams.

Because of its insistence on the importance of individual differences in innate learning abilities, this thesis also runs up against the taboos mentioned earlier, and that is presumably why the relevant literature, mostly dating from the 1970 s, is largely ignored. One of the most subtle attempts to model the processes by which pay and occupation are determined, taking account of natural abilities, is to be found in the concluding chapter of Henry Phelps-Brown's Inequality of Pay ${ }^{6}$, a chapter which builds on an earlier Keynes lecture by James Meade. The social science citations index turns up only one reference to Phelps-Brown's book in the last three years. The book was not to be found in the library which was inherited by the LSE's Centre for Economic Performance from the Centre for Labour Economics.

The way in which these considerations relate to what follows on unemployment will become obvious.

\section{Modern Unemployment}

I would suggest:

1. That the form of unemployment we have in Europe today is in many important respects different from the mass unemployment of the 1930 s -- not very controversial.

2. That there is only limited possibility of making a dent in the unemployment figures by macroeconomic demand management, or by incomes policies and other forms of flexibilization of labour markets.

3. That there are equally limited possibilities of making much impact on the employment intensity of new investment in particular or of the industrial structure in general -- through selective tax or credit incentives, educational initiatives, regional development policies or whatever. 
4. That the main driving force of change which is producing our problem is the steady accumulation of technological knowledge and its impact on the structure of jobs. There is a steady and inexorable increase in the number of jobs which only those with high levels of brain power can learn how to do, and simultaneously a diminution in the number of jobs which almost anybody can learn how to do. The relation between the number of job offers for the latter type of jobs, and the number of people who are not equipped with the necessary skills -- and are not equipped with the mental abilities or habits to acquire the skills -- for any but that kind of job, causes the market-clearing rate for that kind of job to fall, (while, almost everywhere, the shortage of people able to learn to do the difficult jobs drives their wages steadily upwards). In societies where there is no guaranteed social security minimum income, (e.g., the US) that fall in bottom-level wage rates can be charted in the wage statistics very clearly. In societies like ours with a social security floor, the jobs that would only be offered at a wage below that floor don't get offered, and the result is secularly rising unemployment.

5. The statement of the "trend" in the last paragraph in terms of "jobs which only those with a high level of brain-power can learn how to do" and "jobs which almost anybody can learn how to do" is a crude dichotomization of what is really a spectrum of jobs and change is occurring all the way along the spectrum. A nurse has now to learn about a much wider range of procedures and drugs than nurses twenty years ago. Bull-dozer drivers have to learn how and when to punch and pull a much larger set of buttons and levers, and the damage their mistakes can do with their ever-more-powerful machines is increasing. Typists have to learn a new word processing package every two years, if not more often. To be sure, "learning ability" isn't everything. There is still a great range of abilities required for the good performance of the jobs our economy offers -- social skills and personal "presence"; altruistic caring qualities; thickskinned toughness; the conscientiousness to follow precise instructions; imagination. But I would argue that the increasing complexity of our society -- the increasing complexity of our social -- organizational -technology as well as our material technology -- is steadily increasing the importance attached to learning ability/intelligence relative to other factors, all the way down the line.

6. Import competition from (predominantly the labour-intensive manufacturing sectors of) low-wage developing countries accentuates the process of shift in the job structure to more learning-requirement-intensive jobs, though it is not the prime cause thereof $\mathrm{f}^{8}$.

7. The rate at which the "learning burden" of the average job increases may be reasonably assumed to vary with the proportion of their 
collective GNP the rich countries spend on R\&D. That ratio -- currently edging up from two to three per cent -- is increasing at an accelerating rate, as a result of the obsession of national policy-makers with their nation's "competitiveness". Hence, the metaphor "progressive disease" in the title of this paper.

People with long memories are sceptical of this thesis. An American economist comments: "This is not the first time that papers like yours have been written. In 1961-3 there was a wave of forecasts that unemployment could never fall again (i.e. below 7 per cent!) because "automation" had rendered many people unemployable. It turned out not to be true, not remotely true. That does not make it false this time, but suggests caution, anyway." ${ }^{\prime 9}$ It does, to be sure, but there are several pieces of evidence which suggest that this time it might be different, and that the job structure is, now, for the first time, beginning to push up against the limits of available reserves of learning ability.

First, the pioneering statistical survey by the OECD of trends in the dispersion of wages, published in the July 1993 Employment Outlook. The United States stands out as having had the strongest trend for top wages to rise and bottom wages to fall. Britain follows. (These are pre-tax figures, the primary income distribution. ${ }^{10}$ ) Overall, for the 17 countries for which data is provided, it seems reasonable to conclude the following: the more fluid (in OECD mid-1980s doctrine, "flexible") the labour market -- i.e., the less wages are governed by convention or state regulation or collectively bargained agreements, and the more rapidly wages respond to changes in supply and demand and the marginal productivity of labour -- the greater the growth in the gap between the first and the ninth decile wage during the 1980s. Some societies are getting there faster, in other words, and they indicate where market forces might, albeit more slowly, eventually push the other "stickier" societies too.

Secondly, there are the familiar facts about unemployment:

-- a steady secular increase in almost every industrial society from peak to peak and from trough to trough of the economic cycle, an increase which looks less and less like "the impact of the 1973 oil shock, the adjustment to which is still having repercussions", as I heard someone bravely try to assert recently,

-- an equally steady increase in the proportion of long-term unemployed among the residual boom-period unemployed ${ }^{11}--$ 
and, though less well documented ${ }^{12}$, among the less-than -one-year unemployed, an increase in the proportion of those who seem condemned to a career of continuous oscillation between very low paid jobs and unemployment,

-- a steady rise in the correlation between long-term unemployment and low educational attainment ${ }^{13}$.

Thirdly, there are other phenomena which reinforce the simple model which sees the population as distributed along a dimension of what PhelpsBrown in the book cited earlier called ATW, "ability to work", or what might better be called ATAS -- "to acquire skills". The German apprenticeship system is a case in point. More and more young people of the academic attainment levels which previously led normally to apprenticeships are going on to higher education. Apprenticeship schemes are embracing more and more of the least academically able, formerly excluded -- the 24 per cent of the male and 40 per cent of the female workforce with no qualifications in 1975 had declined to 14 per cent and 22 per cent in 1988 and the process continues; there is now, particularly with the demographic contraction of age groups, some kind of place on an apprenticeship scheme for everybody. But this, together with the changes in the job structure is leading to much concern about "quality", to highly controversial proposals for watered-down versions of the apprenticetraining programme for the less able, and to talk of a "crisis" in the system $^{14}$.

As someone who has spent most of his life studying Japan I am often asked: if what you say is true and a universal feature of industrial societies, how is it that the Japanese have such low unemployment? Are you saying that the Japanese are smarter so that they are freed from these ATW, or ATAS, constraints?

It is true that Japan has an exceedingly low unemployment rate even five quarters into a recession. In fact, in good times, complaints of a shortage of labour are frequent. But even there the difficulty of placing children of low educational attainment (the 5 per cent who do not go on from compulsory education to high school) is said by school counsellors to be increasing. (While more adaptable/able/willing illegal Pakistani and Iranian immigrants can still get construction jobs in the recession.)

But so far this hardly shows up in the statistics. Japan keeps a low unemployment rate because of:

(a) a still-high growth rate -- fuelled by a manufacturing output growth rate -- of the kind which more mature industrial societies like ours 
are unlikely ever to attain again. By dint of capturing the markets of its less competitive rivals, as well as generating domestic demand, it has managed to combine higher than average productivity growth in manufacturing with a lesser fall than average in the numbers employed in that sector -- a benign cycle which staves off the "Baumol effect" which plagues the rest of us -- the secular decline in whole-economy productivity growth as more and more of the employed population shift into service jobs with rates of technologically-induced productivity growth much lower than those attained in manufacturing.

(b) a work-ethic, plus a stigmatisation of "living off welfare", which keeps people at work even in the low-wage sector. That ethic derives from earlier periods of poverty; it is one which it is hard to see any affluent society like ours reproducing -- even though manifestly, in our society, people with satisfying jobs -- interesting, prestige -conferring, power-wielding jobs -- are working harder now than they used to before the growth of international trade and the arrival of Japanese imports made us so concerned about our "competitiveness"15.

(c) the job structure produced by any given level of per capita income is dependent on the pattern of consumer demand. Japanese consumers have shown their willingness to buy more services of an anyone-can-learn-to-do kind than in most other societies. They pay higher prices for their petrol for the sake of having two people clean their windscreens rather than one. They pay in higher prices for the pleasure of being bowed onto departmentstore escalators by deferential young ladies. Though how long this will happen as retail-sector competition hots up and discount stores appear is problematic.

(d) there is also, I suspect -- especially after talking with the counsellors who find jobs for the not-so-bright -- a greater tendency in Japan to "employ out of kindness", especially in the small firm sector which is much larger than ours. It is also part of this, I think, that, thanks to convention helped by a government minimum-wage, low-wage jobs are paid somewhat above the market-clearing level.

A further reinforcing consideration for the thesis is the evidence of the progressive realization of what I called earlier the "credentializing" or "diploma disease" trend -- the tendency for access to jobs to depend on performance in general academic education. Sample bits of evidence:

-- the institution and then modification of entrance examinations at Oxbridge, the all-nation character of the competition to get to those universities, the increasingly selective decisions of school-teachers when judging who is 
bright enough to be "put in for" those universities, and the correspondingly increasing value of an Oxbridge degree in the occupational competition.

-- the extension of that process more widely; the systematization of a much more finely graded hierarchy of universities, as publication of the "A-level points average" of each year's entering cohort becomes increasingly important as a determinant of a university's "standing" (and its graduates' job chances) attracts more and more attention and "A-level points average league tables" come to adorn the walls of -- and frame the management objectives of -- more than one vicechancellor.

-- the increasing importance, at the university level of the "milk round", at school level of employer-teacher contacts, reflecting an increasing importance placed by large organizations which can recruit for career employment, on "getting the right human material".

-- as with employing organizations, so with professional bodies. We see a continuation of the process which has been going on for a century -- a steady escalation of the entrance qualifications for various professional bodies. More move from A-level to graduate recruitment, from O-level to A-level recruitment. As a major driving force behind the steady lengthening of general education -- the expected doubling of numbers in higher education, for instance -- this may be a good thing. But note that the escalation of qualifications is not so much the result of a conviction on the part of the councils of the professional bodies that, say, the knowledge or mental capacities gained in a university education are essential to job performance. It is, rather, the result of competition to maintain the status of the profession vis-a-vis others by tapping, in their recruitment, the highest possible level of the "pool of talent".

They can be surer than they ever were before that the assumption underlying the qualification-escalation tactic -- that the further people get in the general educational system the brighter they are -- is a more plausible assumption than ever before as a result of: 
(a) far greater equality of educational opportunity among the nation's children. Even if the differential chances of children brought up in the unskilled working and the children from the chattering classes are great (and likely to grow greater as the mechanisms of assortive mating and genetic inheritance go to supplement those of cultural and economic inheritance), the extent to which Oxbridge creams the nation's children and not just the children of a limited social class has vastly increased. (The point made earlier about increased equality of opportunity a propos of Ernie Bevin; considering only the last 40, rather than the last 80 years, one could equally well cite John Major.) And,

(b) as a result, employers can be far more sure than they used to be that the difference between someone with two passes at O-level and someone with higher scores in six or seven subjects indicates a real difference in the ability to learn on the job.

\section{Prescriptions: Better VET}

So what follows? If this diagnosis of underlying trends and their relation to unemployment is correct, what are the implications, and what are the possible remedies?

Everyone's favourite solution; better education and training. It is rare to find anything written by an economist on unemployment these days which does not end with the pious declaration that -- short-term demand boosts etc. apart -- the only long-term solution to our problems is to improve our education and training. But tackle them on it; ask them if they really have faith in their solution.

One should be suspicious of polyanna recipes. Its much admired educational system and apprenticeship system has not prevented Germany from unemployment edging up to double figures even before the recent recession, and recent German discussion (guarded discussion) of the changing efficacy of apprenticeship as the "quality" of intakes change should give one further pause.

It will be clear from my preliminary remarks, that my scepticism about the "better skill training" solution centres on the fact that its advocates seem never to face up to "pool of ability" questions, the question of exactly how elastic are the learning-ability constraints on efforts to improve skills by improving the quality of family and school life, the efficacy or intensity of instruction, or the incentives to learn. We surely all are aware intuitively of the problem. How many of us think that, given the right opportunities, we could have learned to take on Bobby Fischer at chess? I probably could not have made the grade as a nuclear power engineer, even if I'd had any amount of extra tuition in maths. Most of us are aware not only of our present limitations but of the limits on what we 
might have been. And yet we let pass a great deal of nonsense about education which is implicitly predicated on the notion that anyone can be taught anything. I think the reason lies in the taboos that I talked of earlier, the squeamishness which accounts for the near-disappearance of words like "intelligence" and "brain-power" and "employability" from educationalists' daily talk. To repeat, one can appreciate the kindly concern for the dignity and self-esteem of the not-so-bright which accounts for it. The trouble is that in seeking equality of esteem, we fail to do what we could do for greater equality of life circumstances.

The squeamishness can lead to culpable cant. One of the best examples I know is an advertisement on which the MSC spent thousands of pounds at the time when the Youth Training Scheme was being extended to two years. Full page spreads showed an attractive 17-year-old with a computer manual under her arm. The caption was "Look out Japan. Lindy's coming". Everybody in the business knew that YTS was pretty universally a last resort for those who were unwilling or unable to stay in school, but couldn't get either an apprenticeship or a "proper job". Only in areas where youth unemployment was over 40 per cent (such as Motherwell where I was doing survey work on the YTS at the time) did one find a small number on the scheme with two or three "good passes" at Olevel. Manifestly, few young people with the mental ability to acquire high tech skills were ever going to find themselves on a YTS scheme.

$\mathrm{O} f$ course better education and training is important, but where are the studies which demonstrate how it works? The mechanism is not helping the Lindys to leap into one of the jobs in the top half of the ability/pay range for which there is a skill shortage. It must be something like this. Imagine all the jobs in the economy ranked in terms of a single dimension of "skill-learning requirements". There are shortages of qualified people for most of the jobs in the 85th percentile and upwards. Perhaps somebody in a 70th percentile job could be trained for one of those. And perhaps somebody in the 50th percentile could learn enough to take over his job, and so on down the line until somebody in the 5th percentile job moves up to the 15th and makes way for somebody who is unemployed.

This "bumping up" model clearly needs a lot of clarification. It is exceedingly hard to sort out because the notion of "ability hierarchy" gets entangled with the notion of "career track progression". The observable variable, "deployable skill of this person now", (Phelps-Brown's ATW -ability to work -- or Marshall's "personal efficiency of the worker") is a function of the innate skill -- learning endowment, plus extra-family education and training, plus extra-family education and training. One expects that continuing work experience would raise the ATW somewhat anyway, the more so the "higher" (still in skill-learning requirement terms) 
the career entry level -- though this only within ever-narrowing career tracks up this putative hierarchy. (A redundant accountant who seeks to become a professional footballer carries over very little of his accumulated skills.) The "bumping up" model assumes that some additional VET effort raises the level of a person's ATW (within the total spectrum of ATWs) further and/or faster than would be the case with a normal cumulation of work experience and standard retraining. To do the research which seems urgently needed to assess the real pay-off of training, and to inquire into the reality or otherwise of "ineluctable skill-learning-ability constraints", one has to begin by sorting out what are -- absent intervention -- the normal career tracks.

Such research has to be on case-study lines, requires the collection of new data and cannot be conducted simply by the manipulation of available statistics on e.g., the "success rates" of training schemes. It is crucial research, however -- crucial because, if it seems that there is a wide variation in the efficacy of training, and that this variation is related to the learning-ability of those who receive it -- if, in other words there is evidence that the learning-ability constraints are indeed important but often ignored, this will have important policy implications. For example, in the case of public expenditure, it will make obvious the need to look into the usefulness of diagnostic tests to assess would-be trainees' likelihood of "making it". It will underline also the right of trainees who are in some way paying for their own training to have such independent diagnoses as are available, and not have to rely on the glib promises of trainingproviders who have a clear self-interest in keeping their trainee numbers up.

Moreover, if diagnostic tests are deemed desirable, that has implications for standards and qualifications. You cannot have a diagnostic test without some clear specification of the expected outcomes of training -- which specification the National Council on Vocational Qualifications seems currently bent on making as fuzzy and as assessorvariable as possible!

\section{Alternative Prescriptions: Active Labour Market Policies, etc.}

If it turns out that the efficacy of better education and training is limited, there are, of course, the other seven of the eight proposals which the Financial Times tells us the OECD is about to suggest as solutions for the unemployment problem ${ }^{16}$ : nurture an entrepreneurial climate; enhance the diffusion of technological knowledge; increase wage and labour cost flexibility; reform job security provisions; increase working time flexibility; encourage a switch from passive to active labour market measures, and reform benefit systems to increase work incentives. 
Well, yes, the list is familiar. We can guess roughly what the maximum pay-off from the job-security, flexibility, benefit-system reform measures will be -- getting down from a European 10-12 per cent unemployment level to an American 6-7 per cent level with far more poverty and social deterioration. Active labour market policies? Yes, indeed, Sweden was the finest exemplar, but the slashing of social expenditures and the rise in unemployment from two per cent to eight or nine has shown just how much this was a function of public-sector makework which even the Swedes decided they could no longer afford. Hoursreduction and job-sharing? The enlightened have been advocating this for more than a decade, but so far with little result. It is not only that the leisure/money trade-off shows a declining relative value for leisure as the work-hour average declines below 40. Much less discussed (again, the taboos) is the likelihood that employers will judge it improbable that the 1/2-person whom they bring in from the unemployed work force -- even if the state pays the training cost -- will be less capable of learning to do the job well than the person already doing it, half of whose time the employer would lose. (And he will make that probabilistic judgement on the wholly justified grounds that the unemployed are on average less able than the employed.)

\section{Long-Term Problems: Long-Term Solutions}

For all the OECD's whistling in the dark, it is hard to feel faith in any of the currently offered solutions. If I am right about the progressive nature of the unemployment disease we surely have to begin to ask ourselves: how shall we, in the year 2020, say, succeed in maintaining a society based on what Andrew Britton recently succinctly described ${ }^{17}$ as the Beveridge assumptions,

for those who are able, work is both a duty and a right. It is the basis on which most individuals participate in the community, a source of their social life as well as of their standard of living.

By then, surely it will have become impossible.

The alternatives would seem to be:

(a) Maintain our present link between citizenship -- first-class citizenship -- and participation in paid work, and create the sort of divided society depicted in Michael Young's Rise of the Meritocracy or Kurt Vonnegut's Player Piano, in which the divisions are tempered only by 
welfare transfers of cash to the second-class citizens, and all dignity is denied.

(b) Do something which may not be so very different in terms of economic structure but which could be very different in political and social implications. Seek to break that link between citizen dignity and participation in paid work. The idea of a basic citizen's income has been around a long time. Thanks to James Meade and a slowly growing group of academics grouped around the Citizen's Income Research Group, it has been recently gaining wider currency. Ralf Dahrendorf recently gave it an airing in the Financial Times ${ }^{18}$, stressing the advantages of fiscal and administrative simplicity, avoiding means tests which are both demeaning and an invitation to fraud.

The strongest argument for working, eventually, towards a situation in which something like forty per cent of GNP is distributed as a basic citizen income seems to me to be that which sees the dignity and selfrespect of individual citizens ${ }^{19}$ as an essential precondition for "re-knitting the fabric of society", creating some sense of community and the conditions for a decent polity.

The horrendous fiscal problems of moving to the level of redistribution involved boggle the mind. The slow transfer of capital resources to a national fund so that the basic income is paid partly out of capital income and only partly by redistribution of labour income would seem to be an essential part of any solution, and it is interesting that the OECD report on unemployment is said to be going to urge more taxation of capital income (though in this case for the primary purpose of reducing payroll costs to create employment $)^{20}$.

How does a basic income produce these benign "dignity effects"? In the first place because, although those still capable of taking part in the paid economy would be richer as well as doubtless having a more interesting life, the fact that those living quietly on their citizen's income would include eccentrics and poets and those who hate being organized as well as those not bright enough to get a paid job should take away the indignity, but still make it possible to maintain some kind of social solidarity.

But that alone would not be enough. It seems to me -- and see earlier remarks about "community" -- that an essential accompaniment of a new citizen right to an income would be a new definition of citizen duty. The introduction of some kind of universally obligatory community service seems to me a necessary accompanying measure. It could be highly concentrated in the late teens or spread throughout adult life, but an essential element, to maximise the extent to which such service is not only a symbolic recognition of the claims of community, but also a means of 
opening up personal acquaintanceship networks, would be some kind of social class-mixing teenage dormitory life of the kind the old national service involved. Only thus could one maximise the extent to which such service is not only symbolic recognition of the claims of community, but also a means of opening out personal acquaintanceship networks.

The other key part of an attempt to rebuild community would be to stick to comprehensive schools, and restrain by fiscal measures the growth of private education. (If abolition or nationalisation of the public schools could not get on to the agenda of the 1945 Labour government, nothing but a desperate social crisis would make it thinkable now. Besides, it $\underline{\text { is }}$ difficult to draw the line between -- unacceptably -- saying to parents: "you can spend your money on bingo or a BMW, but you may not spend it on your child's education", and, much more acceptably, saying: "you can spend your money getting your child extra education outside the common school, but not on buying social exclusiveness". (In fact, social exclusiveness and intellectually superior education usually go hand in hand.)

Keeping primary and secondary education as universal and as unsegregated as possible cannot be done, now, after our twenty-year experiment, while maintaining the pretence of the proponents of the original move to comprehensive schools that the change was totally costless because the intellectual development of the brightest children will not suffer. Streaming clearly favours the bright, and the concern of Tory governments to reintroduce selective education stems as much from a concern with national competitiveness and from class interest -- even though all the surveys show that it is the bottom half of our population whose learning performance falls behind that of competitor nations, not the top half.

The question is not simple. It might even be that a small dose of selective education for the very very bright could enhance the sense of community. Probably, the closest approximation to Platonic Guardians on earth at the moment are the hard-working, ill-paid, proud if not sometimes downright arrogant, Japanese elite bureaucrats. In a society which has unstreamed schooling in neighbourhood schools or highly mixed income composition up to the age of 15 , they come increasingly from a tiny group of schools, accommodating not much more than one per cent of the age group, which select at age eleven, strictly by academic merit -- schools whose fees vary but in quite low range so that one really can talk of rationing by ability rather than by the purse ${ }^{21}$. These schools - fewer than thirty of them in a population of 120 million -- have a little bit of the ethos of eliteness and social responsibility of the nineteenth-century British public schools which bred the Indian civil service -- pious arrogance which 
we now scorn. Perhaps, after a decade and a half in which Thatcherites have been doing their best to rubbish the notion of public service as well as of society, we can now, again, do with a little bit of that piety, even at the price of arrogance. What both Plato and Confucius realised -- that a bit of elitism is the price of community -- we have been trying desperately for half a century to forget.

How far institutional changes of this kind would genuinely change social values in such a way as to put more weight on duties as compared with rights and whether that would, in the long term, work against crime and in many other ways improve the quality of life are matters on which one can only speculate, but a subject on which speculation and examination of the evidence (the connection between the greater duty-orientation of a Japan or a Sweden and their lower crime rates, for instance) seems to me urgent. It is a subject even more sadly neglected than the fiscal problems of moving to a basic-income society.

One reason for this is that many of those who are actively promoting the notion of a basic citizen's income (the Citizens Income Trust is a very catholic organization) come to it from the tradition of "claimant activism". All their stress is on an extension of citizen's rights. Talk of national service is seen as reactionary talk, to be heard in its benign form only from the more fuddy-duddy type of one-nation Tories, in its tougher forms only from the advocates of boot-camps etc. to deal with juvenile crime. That seems to me fundamentally mistaken. The fiscal arrangements necessary for a basic citizen's income absolutely require a stronger sense of community than currently exists; and that sense of community cannot be created without a stronger sense of citizen duty counterbalancing citizen rights.

\section{Objections}

There are three major arguments which might be advanced to suggest that the remedy for unemployment suggested above (basically fund it differently and define it differently in value terms) is so pushing against the tide of history as to be hardly worth bothering with.

1. The whole trend of the last three centuries of European history has been for increasing social mobility and fragmentation of traditional communities, increasing complexity of the division of labour and increasing diversity of individuals' "role portfolio", all leading to increasing individuation and increasing individualism. Why should this trend be reversed?

2. The measures I propose for "engineering" a revival of community all presuppose an enhanced role -- in fiscal redistribution, in the 
organization of community service -- for the state. As the economy moves to ever-increasing global borderlessness, as the significance of national frontiers steadily diminishes -- and nowhere more obviously than in Europe after the single market -- how can national-states ever acquire that power?

3. The argument flies in the face of all we know about "hegemonic ideologies". How is it possible that a society dominated by the able workaholics who still participate in the paid economy will sustain a consensual value system which does not accord their activity the highest possible place?

These are, indeed, non-trivial objections, but there are answers -I cannot say overwhelmingly conclusive answers, but answers -- to all of them.

As for the first, one should -- without invoking post-modernism, endof-ideology or end-or-history arguments -- beware of assuming that all historical trends are unilinear. There are also cycles in history, and there are already signs that the extreme boost to individuating tendencies in the Thatcher-Reagan 1980s has evoked a counter-trend. Joe Rogaly, one such trend-spotter, cites not only the publication by the Institute of Economic Affairs(!) of David Green's Reinventing Civil Society, but also Virginia Bottomley's attempt, as Health minister, to ban the word "market" when talking of health service reform ${ }^{22}$. The Guardian, recently rephrasing the early 1980 s battle of the wets and the dries, speaks of an eternal struggle among conservatives "to reconcile a belief in free markets with a recognition of the importance of community" and credits John Major's government with trying to redress the imbalance of the "there is no such thing as society" Thatcher years ${ }^{23}$. The first number of the new journal Demos has a powerful article on America's future by Amitai Etzioni, the sociologist founder of the Society for the Advancement of Socioeconomics, which argues (primarily a propos American society) the need to re-discover the importance of "education to build character" - in the sense of creating the capacity to restrain immediate impulse (to the end not only of "postponing gratification" in order to increase it, but also of showing consideration for others, doing one's duty or obeying internalised moral principles). He argues this in part explicitly as a means of recreating community. Inter alia he too argues for compulsory community service, and claims that it is gaining support from "more and more policy makers"24.

Absolutely crucial for the long-run future of these trends will be the concern of the middle-classes with rising crime rates. This, when politicians are not busy bickering over who raised tax rates most, has become the dominant political issue in both major Anglo-Saxon societies, 
the societies in which individualism is most advanced. Horror pictures of the society of the future are beginning to appear more frequently:

Fifty years ago, the notion of most middle-income earners having their properties protected by an alarm would have been diagnosed as a phobia akin to obsessive hand-washing. By the end of the first decade of the 21 st century those who can afford it will have the bodyguards, the razor wire and the dogs; those who cannot will work in the black economy in which weapons and crack are the units of currency. People will carry handguns, legal or not (the present conditions for a handgun licence being that you are a homeowner with a lockable filing cabinet). No responsible parent will ever allow their child out unaccompanied. Nice young couples will play bridge by videophone and every family will set its own curfew. Your car? Bullet-proofed. Your movements? By day and through decriminalised zones. Your leisure? Zen calisthenics, policed by your own vigilante group ... ${ }^{25}$

The authors' prescription. Start reading. "Start with Auden 'We must learn to love one another or die.""

Maybe, but not all extrapolations predict the future. Michael Howardian repression may work, and in any case the poor and the desperate have the habit of inflicting most of their injuries on each other. Go through Georgetown to the white suburbs and, in Washington city with one of the highest crime rates in the world, you see fewer burglar alarms than you do in Brighton, England. It is beyond my powers of prediction to say whether the creeping, undramatic increase in crime rates will ever be enough to bring the enormous switch in public consciousness necessary to make the reconstruction of community the major objective of any political party. Just think what it will take for typical Daily Telegraph readers to resign themselves to sending their children to a state comprehensive and delaying their university education with national service. That may be all right for the Italians, the French and the Germans who still have national service, but -- well, maybe it is true that in our more class-ridden society it is just a bit harder for a Telegraph or Times

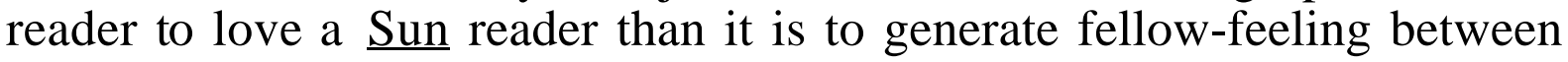
readers of Le Monde and Paris Soir, or of Corriere and Il Giorno. But is that partly because they still have national service? Which is chicken and which is egg, and where do you start if you have neither?

As for the increasing porousness of the nation-state, while it is true that the sense of national community was never higher in Britain than 
during the second world war, and has progressively declined since, there is no inevitable connection between the sense of community and the sort of belligerent patriotism evoked by threats to the nation-state. The way in which the minimally community-conscious Mrs Thatcher was also responsible for the intense revival of belligerent nationalism in the Falklands War is evidence of that. So also is the detachment of a strong sense of community in the Swiss cantons from any nation-state assertiveness on the part of the federated Swiss state (though not, to be sure, from pride in Swissness). Would the relative cohesion of Scotland, qua community, have remained as strong if Scotland had not been absorbed into a United Kingdom?

There is, in other words, particularly in Europe, still the possibility of building more local loyalties, of defining the community which confers income rights, and claims the performance of citizen duties, in regional terms not necessarily coinciding with existing nation-states. Shifting the emphasis of democratic accountability from the single five-yearly vote in parliamentary elections to elections for local hospital, school and welfare and environmental boards, as has been recently suggested as a response to the increasing complexity of administration and consequent dominance by technical experts ${ }^{26}$, is a measure obviously consonant with such an attempt at decentralising democracy and decentralising community. My impression is that not much of the political science literature on federal states is relevant to the assessment of this possibility, but some of it is.

As for the third point -- "hegemonic ideologies" -- a shift in values seems to me not entirely impossible. The crucial point is the dignity one, preventing a first-class/second-class-citizen type of division between those who are lucky enough to have the ability to get paid jobs and those who are not so lucky, or choose not to use their abilities that way. It would mean making success in business or politics or administration something akin to excelling in amateur athletics today. Most people admire the effort, without much envying the luck the champions had in being born with the muscles and lungs that made the effort pay off. As now for athletics, there will obviously be differential material rewards attached to paid work, if there is to be anything like market allocation of scarce talent, and incentives other than honour for the effort which society will need to evoke.

The inevitable difference from amateur athletics is that manifestly the lucky ones will be the ones with the lion's share of power. But, if our democracy can sustain an effective independent press and television, a large group of the clever ones will spend their time ferreting out and exposing to the citizenry any self-interested abuse of power by the others. One cannot rule out the possibility that a shift from a definition of citizenship 
based on participation in paid work, to one based on basic income rights and basic community duties, could be managed without an increase -indeed, thanks to genuinely universal community service, with a decrease -in the quantum of envy which social stratification inevitably generates in any but the most stably traditional societies.

March 1994 


\section{ENDNOTES}

1. R.H. Tawney, (1931), Equality, London: Allen and Unwin.

2. Benjamin Disraeli, Sybil or the Two Nations, first published in 1837.

3. J.R. Behrman et al., (1980), Socioeconomic Success: A Study of the Effects of Genetic Endowments, Family Environment and Schooling, Amsterdam: North-Holland, p.223.

4. See, e.g., Edmondo Berselli, "Gli esorcismi della solidarietà", Il Mulino, Vol. 42, Sept-Oct 1993, p.349. The central point of reference for this discussion in Italy is the notion of the "society of the two-thirds majority" associated with Peter Glotz, the Secretary of the German SPD and the editor of Die Neue Gesellschaft.

5. R. Jowell et al., British Social Attitudes: the 7th Report, SCPR, 1990, p.177.

6. OUP and University of California Press, 1977.

7. "The Inheritance of Inequalities: Some Biological, Demographic, Social and Economic Factors", Proceedings of the British Academy, Vol. 59, 1973, pp.355-81.

8. As demonstrated in Adrian Wood's North-South: Employment, Trade and Inequality, Oxford: Clarendon, 1994.

9. Robert Solow, private communication.

10. "One calculation shows that in Britain changes in the tax and benefit system (most particularly the tax system) tripled the effect of changes in the primary distribution on the dispersion in disposable incomes. P. Johnson and S. Webb, "Explaining the Growth in UK Income Inequality: 1979-88", Economic Journal, Vol. 103, No. 412, March 1993.

11. Chris Pissarides and Jonathan Wadsworth, "Unemployment Risks" in E. McLaughlin, ed., (1992), Understanding Unemployment, Routledge: London and New York.

12. But see Michael White, "Evaluating the Effects of the UK's Restart Programme", mimeo, Policy Studies Institute, May 1992.

13. Pissarides and Wadsworth op.cit. Similar trends can be documented for France and Germany and, among young age groups, Japan.

14. Interventions by Burkhardt Lutz, Christoph Buechtemann and Manfred Tessaring at a conference on HumanCapitalInvestments and Economic Performance, Rand Corporation, November 1993. The figures derive from M. Tessaring, "Das duale System der Berufsausbilding in Deutschland: Attraktivitä und Beschäftigungsperspektiven" ("The German Dual System Apprenticeship: Ability to Attract and Employment Prospects") Mitteilungen aus der Arbeitsmarkt-und Beruforschung, Vol. 2, pp.131 ff.

15. See Juliet Schorr, (1992), The Overworked American, Bellknap: Cambridge MA.

16. 24 Jan 94.

17. Parliamentary Brief, July 1993.

18. 12 January 94. 
19. On the "dignity minimum" and its relation to but difference from the "welfare minimum" see my "Citizenship and Employment in an Age of High Technology", British Journal of Industrial Relations, Vol. XXV, No. 2, July 1987, pp.201-225.

20. $\quad$ Financial Times, 24 Jan 94.

21. See "Equality and Efficiency Trade-Offs: Japanese Perceptions and Choices" in M. Aokiand R. Dore, (1994), The Japanese Firm: Sources of Competitive Strength, Oxford University Press: Oxford.

22. Financial Times, 5 October 1993.

23. Leading article, 12 January 1994.

24. "Learning Right from Wrong", Demos, Issue 1, Winter 1993.

25. Michael Bracewell and Julian Evans, "Anti-Hero for a Razor-Wire Future", The Guardian, 26 December 1993, p.22.

26. See Geoff Mulgan, "Blue-Print for Quality Quangos", Financial Times, 23 November 1993. 